\title{
Higher education as factor of sustainable development
}

\author{
Larisa Sazanova
}

Ural State University of Economics, March 8 Str., 62, 620144 Ekaterinburg, Russia

\begin{abstract}
The paper analyzes the system at higher education in the context of achieving the goals of sustainable development of modern society. From the point of view of a systemic approach, an attempt is made to identify and classify the factors that can measure the contribution of higher education institutions to achieving the Sustainable Development Goals at the regional level. These factors are correlated with the corresponding tasks, as well as possible problems that are posed by the present unstable situation, and hinder sustainable development of the society. The research uses system-wide methods of analysis and synthesis, generalization and analogy. The analysis of the tasks and problems presented in the article allows us to identify and investigate the causeeffect relationships between the factors that determine the achievement of the Sustainable Development Goals and the complexities that accompany this process, and also contributes to the holistic perception of the concept of sustainable development by university staff members and students. The results of the study can be used in event planning within the framework of implementing the strategies drawn up by universities in the context of the sustainable development paradigm.
\end{abstract}

\section{Introduction}

The concept of sustainable development formed the basis of the United Nations Conference on Environment and Development held in Rio de Janeiro in 1992. The summit marked the first international attempt to draw up action plans and strategies for moving towards a more sustainable pattern of development. The concept of sustainable development received its first major international recognition in 1972 at the UN Conference on the Human Environment held in Stockholm. The term was not referred to explicitly, but nevertheless the international community agreed to the notion - now fundamental to sustainable development - that both development and the environment, hitherto addressed as separate issues, could be managed in a mutually beneficial way. The term was popularized 15 years later in Our Common Future, the report of the World Commission on Environment and Development, which included what is deemed the 'classic' definition of sustainable development: "development which meets the needs of the present without compromising the ability of future generations to meet their own needs" [1]. It implies striving to ensure economic growth that does not harm the environment and contributes to tackling social problems. To date, the importance of this topic is constantly increasing, and the concept itself is generally recognized as a global model of the future of civilization [2]. According 
to key conceptual statements, humanity should strive to achieve balance and sustainability in three main areas of development - economic, environmental, and social, thus ensuring the implementation of predictable and favorable scenarios of its future existence. The authors who study sustainable development [3-5], use, as a rule, a systemic approach, when the human civilization is understood as a complex dynamic self-organizing structure that includes social, environmental and economic sub-systems. Each of these sub-systems has its own sub-goals and has direct or indirect impact on the others. At the same time, one of the most frequently mentioned important goals of sustainable development is to ensure access of the majority of the population to quality education. In this regard, to maintain the successful functioning of the national educational system can be considered as one of the global challenges. Responding to this challenge will contribute to attaining sustainable development. In this regard the importance of education is hard to overestimate. The education system that undergoes transformation at all levels and reflects the changing realities of the present time, can build partnership between the participants of the economic process, and contribute to the ongoing industrialization and economic growth. In the modern world the leading position of a country is largely determined by its education system and the use of advanced research and technology in the field of manufacturing and environmental protection.

In various countries, different types of learning may play the leading role in sustainable development. For example, the Chinese national education system is built on the principle of continuous, or lifelong learning both for students and teachers [6]. The application of this principle results in a regular transfer of knowledge, skills and values from one generation to the other. In the UK and some European countries, education and training focus on practical work in schools, local initiatives and extended or additional education, with a growing input of private business. In most developed countries, all spheres of public life information, cultural, economic, and political - are being globalized, one way or another, and education can not stay on the sideline.

For a long time, Russia has ensured sustainable development and stability through the system of higher education. Higher educational institutions (HEIs) are in charge of training teachers, launching initiatives, engaging public and private organizations in the educational process. An important function is also performed by research, development and production facilities that are involved in attaining the Sustainable Development Goals (SDG) in regions. They are also busy with outreach activities, informing and educating the population on relevant issues. Nevertheless, the commitment of many organizations (including educational) to the SDG still remains declarative. In addition, common organizational practices that highlight population environmental and social responsibility can rarely generate profit, which may disincentivize private business partners.

The purpose of this paper is to analyze how the higher education system impacts the process of achieving sustainable development on the national and regional levels. There is a need to correlate the global goals and objectives of modern society in the context of sustainable development with the features of the university education, students' and employers' needs and the challenges posed by the present situation. The latter may demand for designing the teaching and learning process by using new ways of information and educational interaction between teachers and students, as well as the need to update university infrastructure and adjust curricula.

\section{Methods and Materials}

The method of theoretical analysis was used in the research. We analyzed the tasks set for modern universities and challenges for the higher education system as a whole, The research was carried out on the basis of the data collected from Russian and international 
resources and the author's teaching experience. Using the case of the Ural State University of Economics (USUE) in the context of a systemic approach, some features of the studied relationships between the factors were considered. The method of pedagogical observation was used to collect empirical data which cover the teaching and learning experience for the last two years. The impact of new teaching techniques to maximize student research potential was studied. The obtained findings were systematized and generalized.

\section{Results and Discussion}

Sustainable development is traditionally interpreted as the environmentally, economically and socially viable development of a society, leading to its prosperity and well-being. In 2015, the UN adopted Transforming our world: the 2030 Agenda for Sustainable Development. The key goals of the Agenda are to eliminate poverty and illiteracy, preserve human health and natural resources and ensure economic growth. To achieve these goals, the Agenda calls for joint and concerted efforts of governments, civil society and businesses. The management of HEIs also consider sustainable development as a important reference point in decision making. Education for sustainable development is usually understood as a process of creating favorable conditions for social and economic transformations in a society that are required for achieving future sustainability [7]. This concept is based on the universality and continuity of education, the possibility of regular communication between the teacher and the student, as well as the awareness of the need and the creation of conditions for continuous self-learning and self-development. This avenue started to be explored in the early two thousands by the International Community; simultaneously relevant programs were developed at national and regional levels.

To benefit from these opportunities, it is essential to introduce relevant educational, organizational and technological mechanisms that enhance quality assurance and transform the human consciousness in terms of forming a new way of thinking, socially responsible behavior at present and in future. These goals can be attained through inevitable changes in strategic development and planning, as well as through the introduction of information technologies and innovations in teaching and learning. Only then will the national educational system as a whole, and higher education as one of its most important components, contribute to a successful search for effective and constructive solutions of the global problems, thereby increasing the viability of the mankind in unstable environments.

The term 'education' can be interpreted as a lifelong process that includes pre-school education, professional training and autonomous learning. Any education system should be consistent with the goals of country's development and contributes to stable and balanced scenarios of its further existence, i.e. to three interrelated processes:

1) economic growth;

2) social responsibility of the members of the society;

3) ecological balance on a regional or other scale.

Since higher education is involved all three processes, its leading role becomes apparent. From the very beginning the idea of sustainable development came from environmental education, but only the equal development of all its components environmental, economic, social, psychological, medical etc. - makes it possible to meet global challenges. In a broad sense, education, as a factor determining sustainability and development, is an important tool for achieving the above-mentioned goals. Education should provide not only the acquisition of knowledge and skills in the chosen field, but also should help obtain individual humanistic values of a modern society, such as mutual understanding, harmony and social stability.

Sustainable development in a single HEI largely depends on its well-balanced strategy that should include teaching and learning, research, collaboration with different groups of 
stakeholders (e.g., parents, employers, regional public bodies). The successful solution of the corresponding tasks characterizes the university contribution to raising a human being as a member of a growing and sustainable society who can bear responsibility for a taken decision, as individual involvement or lack of involvement in various events can have a direct impact on the emergence or solution of non-trivial environmental, economic, social, political, and other problems. At the same time, it is education that develops critical thinking skills and qualities necessary for an adequate perception of the changing reality, forecasting and group decision making. The modern education system can cope with this complex task if each single educational institution works on new approaches to teaching and learning.

According to [8], education for sustainable development should meet the following criteria: it should be universal and accessible; have the government support; combine education and upbringing; integrate advanced knowledge. Researchers identify a number of principles which can ensure that the criteria are satisfied. These might include: a variety of teaching methods and techniques; flexibility and adaptability; the continuity of educational programs at different levels, and inter-disciplinarity, to name just a few.

It is possible to identify a number of factors that a university can used to achieve the SDG. Using the case of USUE [9], Table 1 presents the most important factors, grouped as follows: the key tasks (sets of tasks), priority areas of task solutions; and risks that can complicate the solution of these tasks.

Table 1. Factors affecting SDG achievement on a university side

\begin{tabular}{|c|c|c|}
\hline Tasks & Priority areas & Risks \\
\hline $\begin{array}{l}\text { Diagnosis of sustainable } \\
\text { development issues and } \\
\text { analysis of their solution }\end{array}$ & $\begin{array}{l}\text { Studies of the issues; university } \\
\text { conferences and seminars on the } \\
\text { relevant topics }\end{array}$ & $\begin{array}{l}\text { Lack of clear understanding } \\
\text { on management side; lack of } \\
\text { clearly defined areas in } \\
\text { regional programs }\end{array}$ \\
\hline $\begin{array}{l}\text { Carrying out and justification } \\
\text { of managerial decisions in the } \\
\text { field of sustainable } \\
\text { development }\end{array}$ & $\begin{array}{l}\text { Sharing best practice between } \\
\text { universities and cooperation } \\
\text { with regional bodies (other } \\
\text { educational institutions, local } \\
\text { authorities, R\&D organizations, } \\
\text { research and manufacturing } \\
\text { facilities) }\end{array}$ & $\begin{array}{l}\text { Time constraints due to } \\
\text { complex analysis of research } \\
\text { outcomes and best practices }\end{array}$ \\
\hline $\begin{array}{l}\text { Introduction of sustainable } \\
\text { development techniques in a } \\
\text { university performance }\end{array}$ & Joint efforts of all stakeholders & $\begin{array}{l}\text { Lack of clear understanding of } \\
\text { techniques and their } \\
\text { application }\end{array}$ \\
\hline \begin{tabular}{lrr} 
Re-focusing & university \\
development & \multicolumn{2}{c}{ programs } \\
considering & social & and \\
economic perspectives &
\end{tabular} & $\begin{array}{lrr}\begin{array}{l}\text { Integration } \\
\text { professional } \\
\text { education }\end{array} & \begin{array}{r}\text { of } \\
\text { and }\end{array} & \begin{array}{r}\text { general, } \\
\text { ecological }\end{array} \\
& & \end{array}$ & $\begin{array}{l}\text { Time constraints due to new } \\
\text { program design and } \\
\text { modification }\end{array}$ \\
\hline $\begin{array}{l}\text { Continuity of programs at } \\
\text { different levels (bachelor, } \\
\text { master, post-university) }\end{array}$ & $\begin{array}{l}\text { Interdisciplinarity of university } \\
\text { courses, program adaptability, } \\
\text { quality research and technical } \\
\text { information transfer, relevance } \\
\text { of the courses to professional } \\
\text { and innovative activities }\end{array}$ & $\begin{array}{l}\text { Shortened optional courses; } \\
\text { overlapping topics in different } \\
\text { subject programs }\end{array}$ \\
\hline $\begin{array}{l}\text { Enhanced teacher training } \\
\text { framework } \\
\text { collaboration with research } \\
\text { and manufacturing facilities }\end{array}$ & $\begin{array}{l}\text { Close collaboration with } \\
\text { employers (e.g. annual 'The } \\
\text { Best USUE Partner Employer' } \\
\text { reward) }\end{array}$ & $\begin{array}{l}\text { Lack of university staff } \\
\text { awareness and interest }\end{array}$ \\
\hline
\end{tabular}


Table 1. Continied

\begin{tabular}{|l|l|l|}
\hline $\begin{array}{l}\text { Building innovative networks } \\
\text { of additional education } \\
\text { programs }\end{array}$ & $\begin{array}{l}\text { Pedagogical innovations, 'The } \\
\text { Best Teacher' contests; sharing } \\
\text { best practices between } \\
\text { universities; incentive schemes } \\
\text { for investors to introduce } \\
\text { resource-saving technologies }\end{array}$ & $\begin{array}{l}\text { Lack of a systemic approach; } \\
\text { lack of interesting and original } \\
\text { content for program design }\end{array}$ \\
\hline $\begin{array}{l}\text { Timely and complete resource } \\
\text { provision (human resources, } \\
\text { teaching and learning } \\
\text { materials, material support, } \\
\text { information support) with the } \\
\text { priority of innovative } \\
\text { management techniques }\end{array}$ & $\begin{array}{l}\text { Project implementation, e.g. } \\
\text { 'Information Didactics',E- 'E- } \\
\text { lextbooks' regular update of } \\
\text { site; career planning; } \\
\text { cooperation with data analytics } \\
\text { portals of }\end{array}$ & $\begin{array}{l}\text { Lack of time to work on e- } \\
\text { textbooks and lectures due to } \\
\text { academic staff work overload; } \\
\text { a need to regularly upgrade } \\
\text { lassroom and library } \\
\text { technical facilities }\end{array}$ \\
\hline $\begin{array}{l}\text { Creation of comfortable } \\
\text { educational environment }\end{array}$ & $\begin{array}{l}\text { Alternative incentive schemes } \\
\text { (e.g. corporate events) for } \\
\text { academic staff and students }\end{array}$ & $\begin{array}{l}\text { Low degree of junior students } \\
\text { involvement in university } \\
\text { events }\end{array}$ \\
\hline $\begin{array}{l}\text { Broader international } \\
\text { educational cooperation }\end{array}$ & $\begin{array}{l}\text { Hosting international forums, } \\
\text { contests, meetings and } \\
\text { conferences }\end{array}$ & $\begin{array}{l}\text { Restrictive measures due to } \\
\text { the COVID-19 pandemic }\end{array}$ \\
\hline $\begin{array}{l}\text { Development of skills and } \\
\text { values to ensure sustainable } \\
\text { development and education } \\
\text { for citizenship }\end{array}$ & $\begin{array}{l}\text { Educational activities and work } \\
\text { at all organizational levels }\end{array}$ & $\begin{array}{l}\text { Low degree of student interest } \\
\text { and inertia }\end{array}$ \\
\hline
\end{tabular}

In the context of a systemic approach, it should be considered that the relationships between factors of different groups and within groups can be quite complex, indirect, and multi-staged. For example, the restrictive measured caused by the COVID-19 pandemic can have a negative impact on the solution of most tasks or, to some extent, delay positive results. Then, since the goal of achieving sustainable development is a large-scale, multicomponent, and complex system that requires relevant research and resources, many methods that can be used to attain this goal cannot be simple. The tasks set to achieve this goal are interrelated and require an integrated approach to their analysis, which causes inherent difficulties in finding solutions. In particular, the SWOT analysis can be one of the universal and, at the same time, flexible methods used for the strategic development and consideration of possible scenarios. This analytical tool can be applied to a university as a whole or to its divisions and strategic units of different levels of management in order to identify their strengths and weaknesses and related external circumstances. Next, it is essential to work on programs and plans not so much at the level of a single university, but within the framework of a regional and state strategy. In the latter case, it might result in the establishment of regional centers of economic growth with the university involvement, which might reinforce the regional and state development.

Finally, the design of a system of indicators that can measure the university achievement of the SDG may also cause some difficulties. This system should include both quantitative and qualitative measuring instruments. For example, these may be access to relevant information by all participants of the educational process; satisfaction with the quality of education; the proportion of students interested in research and innovation; the number of participants in university events. These indicators can be grouped on the basis of the impact on the final outcome, e.g. the input effect indicators, the indicators of state management. The indicative lists of these indicators are recommended by the UN Commission on Sustainable Development $[10 ; 11]$. It is also possible to choose one or several aggregated indicators that reflect the degree of sustainable development of the analyzed system [12]. 


\section{Conclusions}

Despite its rather long existence, the concept of sustainable development as a reference point remains quite new for most Russian educational institutions and the education system as a whole. The latter is still at the stage of goal definition and strategic program design. Changing organizational systems defines their role in achieving the SDG in different ways. HEIs should take this fact into account when selecting teaching and learning methods and techniques, quality assurance techniques and developing long-term plans as the main tools for sustainable development and in the context of achieving regional goals. Special attention should be given to building and consolidating relationships with various stakeholders (partners, employers, government agencies, research and industrial associations), as well as to teacher training, experience sharing and skill development.

Since the socio-economic policy in many regions is still being formed, universities have to adjust their plans, which results in a constant modification of goals, objectives and actions. Thus, in order to successfully contribute to sustainable development, HEIs need to assess their potential and, if necessary, review long-term goals taking into account modern realities. These tasks can be solved on the basis of the following prerequisites: (1) an advanced organization of the educational process; (2) optimization of the university material and human resources, which will lead to the growth of the number of academic staff and students who support the principles of sustainable development and are able to implement them; (3) education of the younger generation in the traditions of civic responsibility, preservation of health and environmental protection. The successful implementation of these measures might maintain a balance between the economic, environmental and social components of a modern society, which reduces its vulnerability and ensures the formation of resilience.

\section{References}

1. ESD National Strategy. Russian Federation, http://www.unece.org/

2. V.R. Partsvania. Russian Management Journal, 18, 1 (2020)

3. A.A. Dokukina, E.K. Pukhova, Human capital and vocational education, 2 (2014)

4. E.V. Korchagina, Questions of economic theory. Macroeconomics, 1 (2012)

5. A. Belke, A. Zenkov, L. Sazanova. E3S Web of Conferences, 1, 09010 (2020)

6. A.A. Krasnova. Vestnik RUDN, Informatization of education, 3 (2015)

7. S.V. Zakharova, L.G. Tarshis, M.Yu. Mamontova, International research journal, 11, $101(2020)$

8. V.V. Zinchenko, Perspectives of Science and Education, 2, 44 (2020)

9. Ural State Economic University, https://www.usue.ru/

10. E. Dolgikh, V. Erlich, Sustainable Development. Role of Russia. UN Global Compact Russia (2018) http://www.globalcompact.ru/

11. C. K. Chase-Dunn, Global Formation. Structures of the World-Economy, Cambridge: Blackwell Publishers (2015)

12. V. Sintschenko, Globale Transformationen der Gegenwart, Band 1, Systemischen globale Transformation, Saarbrücken:Palmarium Academic Publishing (2017) 